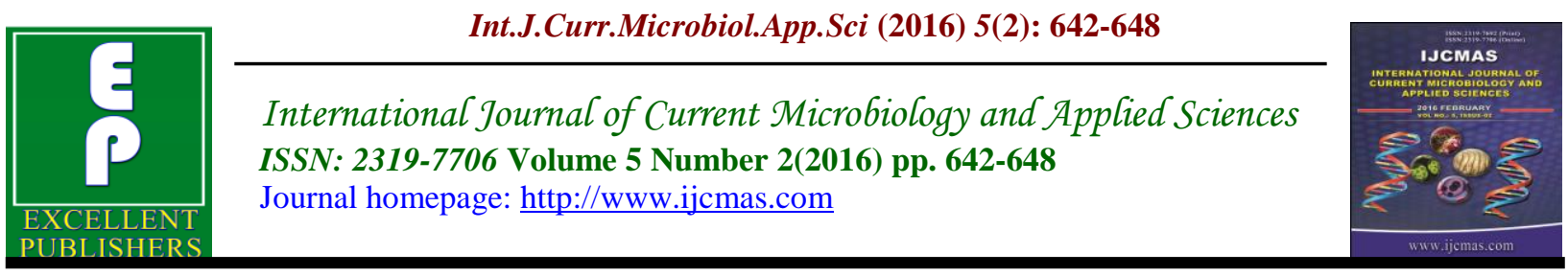

Original Research Article

doi: http://dx.doi.org/10.20546/ijcmas.2016.502.072

\title{
In Vitro Efficacy of Lytic Bacteriophage against Antibiotic Resistant Bacterial Pathogens
}

\author{
T. Vishwanatha ${ }^{1 *}$, M. Keshavamurthy ${ }^{2}$, K. G. Siddalingeshwara ${ }^{3}$ and D. Kavyashree ${ }^{1}$ \\ *1 Department of Microbiology, Maharani Science College for Women, Bangalore-560 001 , \\ Karnataka, India \\ ${ }^{2}$ Department of Microbiology, Gulbarga University, Kalaburagi - 585 106, Karnataka, India \\ ${ }^{3}$ Scientific and Industrial Research Center, Yeshwanthpur Industrial area, Bangalore-560 022 , \\ Karnataka, India \\ *Corresponding author
}

Keywords

Antibiotic resistance,

Bacteriophage, Sewage and lytic activity.

\section{Article Info}

Accepted:

29 January 2016

Available Online:

10, February 2016
A B S T R A C T

In the present study Sewage effluent samples were collected from in and around the Bangalore city and clinical bacterial pathogens like Staphylococcous aureus, Escherichia coli, Klebsiella sps were isolated from clinical samples collected from hospitals. The in vitro efficacy of isolated lytic specific phages was determined by spectrophotometric method. The Optical density decreases after 40mins. The host specific Phages showed maximum lytic activity against specific bacteria. The research outcome of this work has been initiated to expose the potential application of bacteriophage in bio control agent clinically pathogenic bacteria.

\section{Introduction}

Bacterial viruses or Bacteriophages constitute a group of viruses that can specifically target, infect and lyse bacteria. The discovery of antibiotics was perhaps one of the great breakthroughs in medicine by $20^{\text {th }}$ century. However, the emerging of antibiotic resistant bacteria (super bugs) due to indiscrimmate use of antibiotic is posing a great threat. Bacteriophages could prove to be promise alternative to antibiotics, due to their persistency, inactiveness and nonPathogenicity outside their host bacterial cells (Duraisamy et al. 2015).
Phages are also help in regulating microbial balance in ecosystem. Natural sources of the environment such as sewage, soil and water has been considered as sources for the isolation of phages. (Bitton, 1987; Kutter, 2001; Mathur et al. 2003; Kevin et al. 2003)

The economic impact of managing infections caused by antibiotic resistant bacteria is substantially high (Harrison \& Lenderberg 1998). As Bacterial Multi Drug Resistance (MDR) is serious worldwide problem, for which development of novel antibacterial therapeutic must become a high 
priority (Caraline et al. 2003). The bacterial pathogen tends to develop resistant even to the newer generations of antibiotics. The host specific property of phages offers a tool to fight against bacterial infections. The ability of phages to control bacterial populations has been extended from medical applications to other fields like agriculture, aquaculture and food industry. Those Phages undergoing lytic cycles are virulent. The Lytic cycles consistitutes series of events and show considerable variations according to the type of phage (Pavani 2015). However, the progressive increase in antibiotic resistance among bacterial pathogens in developing countries is becoming a critical area of concern. In addition, the overuse and misuse of antibiotics in the treatment of infections could lead to an increase of antibiotic resistance, S. aureus, E. coli and Klebsiella species which is most commonly isolated from clinical samples of patients and shows a high prevalence of resistance to antibiotics. In the present study we isolated and identified host specific bacteriophages and antibiotic resistant pattern of selected bacteria pathogens.

\section{Materials and Methods}

\section{Isolation of Clinical Pathogens}

The patients suffering from Pyogenic and Urinary Tract Infections (UTI) admitted at three major local hospitals in Bangalore, Karnataka were the sources for the clinical samples. Pus samples were collected from the site of pyogenic infection of the patients by wet and dry dual swab technique (Mackie \& Mac Cartney, 1990). The sterile swabs along with the pus collected were immersed into screw cap tubes containing $1 \%$ sterile peptone water and brought immediately to the laboratory for further studies. Urine sample were collected from different wards.
These samples were cultured on nutrient agar plate and incubated at $37^{\circ} \mathrm{C}$ for 18 hours.

\section{Characterization of Isolated Bacterial Pathogens}

The Colony characteristics of all bacterial pathogen obtained on the basal medium were observed and recorded after the incubation at $37^{\circ} \mathrm{C} 24-48 \mathrm{hrs}$. The isolates were further studied based on their microscopic features and biochemical tests as per the procedure prescribed by Barrow and Felthan 1993 and Collin et al 1995. The Sugar fermentation test was performed using Carbohydrate fermentation broth where bromocresol purple was used as an indicator was prepared with different sugars like glucose, galactose, lactose, and sucrose. The test isolates were inoculated and incubated at $37^{\circ} \mathrm{C}$ for $24-48 \mathrm{hrs}$ and acid production in medium was recorded by change in color from purple to yellow and gas production by observing the gas in Durham's tube.

\section{Antibiotic Susceptibility Test}

Kirby Bauer's (1966) disc diffusion method as per NCCLS standards was employed to study the antibiotic susceptibility pattern of all the confirmed clinical isolates - S.aureus, E.coli and Klebsiella sps against six antibiotics. The results were recorded as sensitive, intermediate and resistant as per the CLSI guidelines, 2013 depending on the zone of inhibition in mm diameter exhibited by each bacterial pathogen against each antibiotic.

\section{Source, Isolation and Enrichment of Host Specific Phages}

Sewage sample was collected in and around the Bangalore city for the isolation of Bacteriophage. $5 \mathrm{~mL}$ culture of the test 
isolates of bacteria (S.aureus, E.coli and Klebsiella sps) and $5 \mathrm{ml}$ of double strength LB broth were added to the $45 \mathrm{~mL}$ of pretreated sewage samples separately in a sterile container and kept for incubation overnight at $37^{\circ} \mathrm{C}$. The overnight-incubated mixture was centrifuged at $8000 \mathrm{rpm}$ for 10 min. Supernatant was filtered through membrane filters $(0.22 \mu \mathrm{m})$ and the filtrate was collected. Phages were isolated from all the enriched samples by double layer agar method (Smith and Huggins, 1982 and Sambrook et al 1989) against antibiotic resistant S.aureus, E.coli and Klebsiella sps respectively. 2-3 drops of filtrate and $0.1 \mathrm{~mL}$ of the overnight incubated test bacterial culture were added to $5 \mathrm{~mL}$ soft agar maintained in tubes through water bath at $45^{\circ} \mathrm{C}$. This mixture was transferred on to hard agar plates of LB media and kept for incubation after solidification for overnight at $37^{\circ} \mathrm{C}$. After the incubation, the plates were observed for the formation of plaques. A prominent plaque was harvested with a loop and added to $10 \mathrm{ml}$ of overnight incubated test culture and incubated for 6-8 hrs at $37^{\circ} \mathrm{C}$ to achieve the maximum number of phages (Gowri S, 1998 and Sambrook et al 1989).

\section{Screening of Phages for their In vitro Activity}

All host specific phages were screened by spot culture method (Matsuaki et al 1992) for their specific lytic activity against clinical isolates of drug resistant S.aureus, E.coli and Klebsiella sps. A culture of bacterial pathogen was layered on the surface of nutrient agar by L - shaped glass spreader. $100 \mu \mathrm{l}$ test phage was spotted on the layer of bacterial culture at distance of 1 $\mathrm{cm}$ and kept for incubation at $37^{\circ} \mathrm{C}$ for overnight. Plates were observed after incubation for clear area around the spot of phages as zone of inhibition and were measured. The in vitro lytic activity of prominent phages against specific targeted drug resistant bacteria pathogens was examined by spectrophotometric and titer value methods.

\section{Spectrophotometric Method}

The suspension of drug resistant bacterial test isolates were prepared and OD was adjusted to 1.0 at $600 \mathrm{~nm} .100 \mu$ of isolated phage $\left(10^{3} \mathrm{pfu} / \mathrm{ml}\right)$ solution was added to the bacterial suspension and OD was measured at the interval of every $5 \mathrm{~min}$ up to $45 \mathrm{~min}$ (Sandra et al 2004).

\section{Results and Discussion}

Positive bacterial cultures were examined by Gram stain and biochemical test for the purpose of identification of S. aureus, E. coli and Klebsiella sps. All 75 clinical samples obtained (Table-1) from wounds, abscesses, post operative infections, and urine for the isolation of S.aureus, E.coli and Klebsiella sps. The maximum number of samples were collected from wounds (25) and Urine (25) followed by abscesses (15) and post operative infections (10). The bacterial colonies were selected based on the standard colony features and pigmentation was confirmed further based on a set of biochemical test (Table 1). The isolated $S$. aureus, E. coli and Klebsiella sps. were confirmed by their specific characteristics features on selective media (Plate-1). The emergence of antibiotic resistant clinically important bacteria has prompted interest in alternatives to conventional antibacterial agents (Kutter 2001). Bacteriophage isolated from sewage effluents on the specific bacterial lawn resulted in the formation of plaques. The morphological features of plaques such as shape, size and opacity. All respective plaques were considered for further studies based on their prominent morphological features (Plate-2). 
The antibiogram of all confirmed clinical isolates of S.aureus (30), E.coli (20) and Klebsiella sps. (15) were recorded based on the degree of zone of inhibition with individual antibiotics and shows typical antibiotic susceptibility pattern of representative isolates as sensitive, intermediate and resistant.

Plate-1: Antibiotic susceptibility pattern of clinical isolates

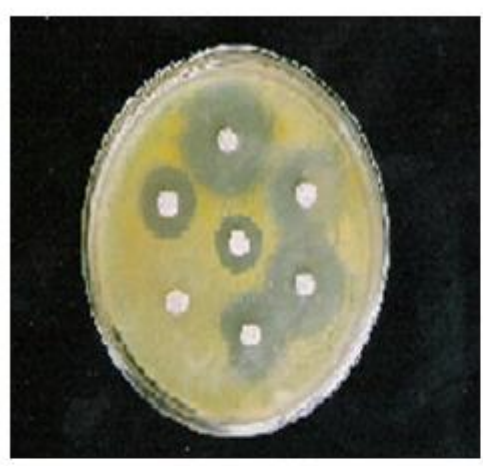

S. aureus

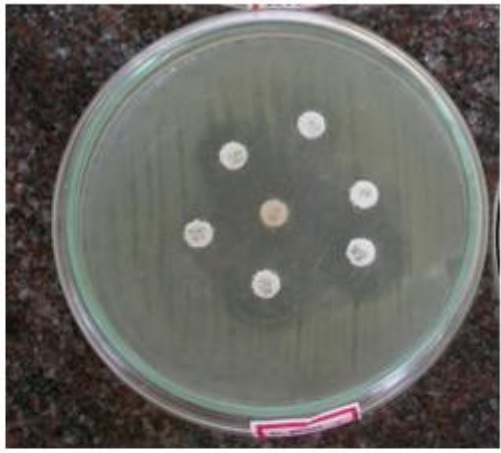

E. coli

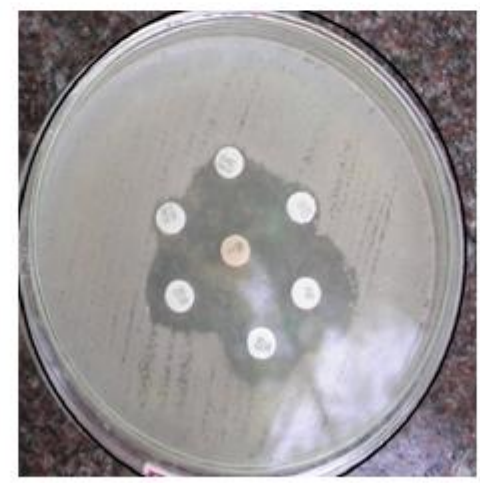

KlebsiellaSps

Table.1 Biochemical test for clinical isolates

\begin{tabular}{|c|c|c|c|}
\hline Biochemical Tests & S. aureus & E. coli & Klebsiella sps. \\
\hline Indole & $-\mathrm{ve}$ & + ve & -ve \\
\hline Methyl red & $+\mathrm{ve}$ & + ve & -ve \\
\hline Vogues Proskauer & $+\mathrm{ve}$ & -ve & $+\mathrm{ve}$ \\
\hline Citrate utilization & $-\mathrm{ve}$ & -ve & + ve \\
\hline Oxidase & -ve & -ve & -ve \\
\hline Catalase & $+\mathrm{ve}$ & + ve & + ve \\
\hline Gelatin liquefaction & $+\mathrm{ve}$ & -ve & -ve \\
\hline Glucose & $+\mathrm{ve}$ & -ve & -ve \\
\hline Lactose & $+\mathrm{ve}$ & $+\mathrm{ve}$ & $+\mathrm{ve}$ \\
\hline Sucrose & $+\mathrm{ve}$ & -ve & $+\mathrm{ve}$ \\
\hline Galactose & $+v e$ & -ve & -ve \\
\hline
\end{tabular}




\section{Plate-2: Morphological features of plaques}

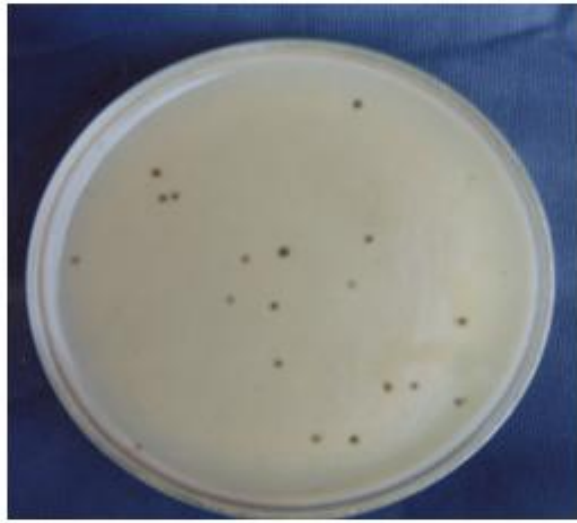

S. aureus

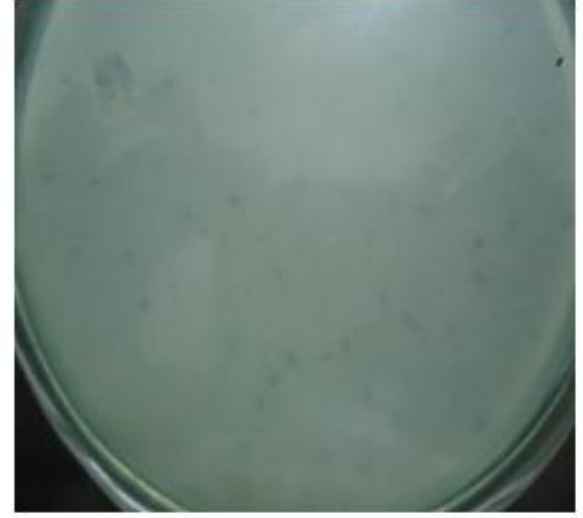

E. coli

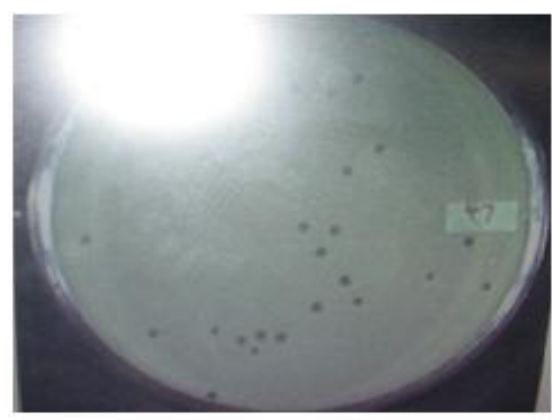

Klebsiellasps

In vitro lytic activity of three selected bacteriophages SAP016, ECP02 and KSP03, after their screening was determined by spectrophotometric method (Fig.-1). A gradual decrease in the optical density of host cells was observed from $10^{\text {th }} \mathrm{min}$ onwards upto $45 \mathrm{~min}$. Phage SAP01 had shown high degree of lytic activity against $S$. aureus. Phage ECP02, which had shown a linear effect against E.coli and Phage KSP03, which has shown variations in its lytic activity along the course of the time of incubation against Klebsiella sps.

In conclusion, the use of bacteriophage as an alternate to antibiotic therapy for bacterial infections is being reappraised because; antibiotic resistant pathogens have emerged as an increasingly serious threat to disease treatment. Novel and effective approaches for treating infections caused by antibiotic resistant bacteria are urgently required. Phages may provide a safe and effective modality for dealing with multidrug resistant pathogens. Nevertheless, because of the current novelty and aspirations for phage therapy as an alternative to antibiotics, it seems appropriate to acknowledge that our results and those of several other studies offer promise that, phage therapy is highly repeatable, can be successful, and is thus worthy of further research for clinical practice. This study has confirmed that a host specific bacteriophage, which is active and lytic in vitro against Multi drug resistant S.aureus. E.coli and Klebsiella sps. The 
results reveal that, the detected specific phage as a potential antibacterial agent has all the efficiency for the prevention and treatment of infections induced by multi drug resistant S.aureus. E.coli and Klebsiella sps. Because of the increasing problems of bacterial antibiotic resistance worldwide, it would seem timely to begin to look afresh at this approach and begin a period of renewed and rational assessment. However, the site specificity and safety profile of the phage as a novel bio-therapeutic agent need to be explored.

\section{Acknowledgement}

Authors wish to acknowledge the financial support provide by University Grants Commission (UGC) New Delhi, India to carry out this research work.

\section{References}

Barrow, G. I. and Felthan, R. K. (1993).Cowan and Steels manual for the identification of medical bacteria. Cambridge University Press, Cambridge

Bitton, G. (1987). Fate of bacteriophage in water and waste-water treatment plants, in phage ecology, Ed. by Goyal S. M., Gerba, C. P. and Bitton, G. H. 81-195.

Caraline, W., Laura, M. Kasman, David, A. Schofield, Phillip, A. Werner, Joseph W. Dolan, Michael G. Schmiat and James S. N. (2003). Use of genetically engineered phage to delwer antimicrobial

agents to bacteria: an alternative therapy for treatment of bacterial infections. Antimic. Agents and Chemo. Thera. 47(4): 1301-1307.

Collins, C. H., Partrica, M., Lyne and Grenge, J. M., Collins and Lyne's
(1995). Microbiological methods. $7^{\text {th }} \mathrm{Ed}$.

Duraisamy, N., Nachimuthu R., Vaithilingam K., Pandiyan R., Ebenezer K.S., Velu R.K. (2015). Distribution, Isolation and Characterization of Lytic Bacteriophages against Multi-Drug Resistant and Extended-Spectrum of B-Lactamase Producing Pathogens from Hospital Effluents. Asian J Pharm Clin Res, 8(2): 384-389

Flynn, G. O., Ross, R. P., Fitzgerald, G. F. and Coffey, A. (2004). Evaluation of a Cocktail of three bacteriophages for biocontrol of Escherichia coli 0157:H7. Appl. Environ. Microbial 70 No 6: 3417-3424.

Gowri S.R., Madhusudhan, V. and Palaniappan, P. (1998). Evaluation of phage therapy to treat experimental infections in mice. In. J. of Microbiol. 38: 101-103.

Clinical Laboratory Standards (CLS). (2013). Methods for dilution antimicrobial susceptibility tests for bacteria that grow aerobically, $5^{\text {th }} \mathrm{ed}$. NCCLS document M7 - 45. Wayne, P. A., NCCLS.

Harrison, P. F. and Lederberg, J. (1998). Antimicrobial resistance issue and options. National Academy press, Washington, D. C. Workshop summary, 1-7.

Kevin, E. A., Martin, J. D., and John, C. F. (2003). Elevated abundance of bacteriophage infecting bacteria in soil. Applied and environmental microbiology, 69(1): 285-289.

Kirby, A. W., W. M. M., Sherris, J. C. and Truck, M. (1966). Antibiotic susceptibility testing by a standardized simple disc method. Am. J. Clin. Path 45:493-496.

Kutter, E. B., (2001). Bacteriophage as natural, self-replicating and self- 
limiting antibiotics. Astrazeneca research foundation India.

Mathur, M. D., Vidhani, S. and Mehndiratta, P. L. (2003). Bacteriophage Therapy: An alternative to conventional antibiotics. JAPI, 51:593-596.

Mackie and McCartney (1990). Practical Medical Microbiology, $13^{\text {th }}$ edition, Vol. II.

Matsuaki, S. Tanaka, S., Koga, T., Kawata, T. (1992). A broad-host-range Vibrio-phage, KVP40, isolated from seawater, Microbiol Immunol, 36:937.

Pavani G. (2015). Bacteriophages: their use in the treatment of infections in the future. Int.J.Curr.Microbiol.App.Sci 4(2): 897-879

Sambrook, J. E. F., Fritsch and Maniatis T. (1989). Molecular cloning: a laboratory manual $2^{\text {nd }} E d$. Cold Spring Harbor Laboratory Press, Cold Spring Harbor, N. Y.
Sambrook, J. and Russell, D. W. (2001). SDS-polyacrylamide gel electrophoresis of proteins. In: Molecular Cloning: A laboratory manual, Argentine J. (Ed.), Cold Spring Harbor Laboratory Press, 3:A8.40-A8.51.

Smith, H. W. and Huggins, M. B. (1982). Successful treatment of experimental E. coli infections in mice using phage: its general superiority over antibiotics. J. Gen. Micr. 128:307318.

Sandra, C. C., Josette, S., Anne, B., Elizabeth Kutter, Shafiq, S. and Harald, B. (2004). In vitro and in vivo bacteriolytic activities of Escherichia coli phages: Implications for phage therapy. Antimicrobial agents and Chemotherapy. 48(7): 2558-2569.

\section{How to cite this article:}

Vishwanatha, T., M. Keshavamurthy, K. G. Siddalingeshwara and Kavyashree, D. 2016. In Vitro Efficacy of Lytic Bacteriophage against Antibiotic Resistant Bacterial Pathogens. Int.J.Curr.Microbiol.App.Sci. 5(2): 642-648. doi: http://dx.doi.org/10.20546/ijcmas.2016.502.072 